\title{
The status of and recent trends in forest sector research in British Columbia
}

\author{
by Clark S. Binkley ${ }^{1}$ and Susan B. Watts ${ }^{2}$
}

In the decade between 1988 and 1998, expenditures on forest sector research in British Columbia have increased substantially in absolute terms but have fallen in relation to the scale of the province's forestry enterprise. These aggregate trends mask important shifts in funding sources and in the specific fields of research that have been supported. The crown corporation Forest Renewal BC has emerged as the dominant source of support for forestry research, clearly displacing appropriated funds within the B.C. Ministry of Forests. As a result of falling stumpage fees and changes in forest policy, this source of support is now declining and the long-term security of the Forest Renewal BC research program is in question. At present, expenditures on forestry research are more or less consistent with expenditures on forestry research in other advanced forested jurisdictions, but the anticipated decline in Forest Renewal BC research support belies this otherwise favourable finding. Expenditures on forest products research in the province have not matched their counterparts elsewhere in the world, and recently have declined precipitously. Forestry - forest conservation, management, products and production processes - is becoming ever more complex. Research activity in the province does not appear adequate to sustain the flow of economic and ecological wealth from forests that British Columbians have always enjoyed and have come to expect.

\section{Introduction}

We first examined forest sector research early in this decade (Binkley and Watts 1992) based on a survey commissioned by the British Columbia Forestry Research Advisory Committee (BCFRAC) in 1991. The objective of that project was to assess how much was being spent on forestry-related research, in what specific areas and by whom. It was of particular value as no other sources provided such primary data on research expenditures in B.C. Research managers and policy analysts found those data interesting and helpful; hence this redux including both an updated status report and an assessment of trends.

This report is based on the same 10 research categories that were used in 1991/92 but with additional information-gathering relating to Forest Renewal BC priority research areas. By keeping the same basic structure of survey, we were able to compare forestry-related research expenditures over the past six years, and to extend these comparisons back a decade through the use of roughly comparable information collected by others.

\footnotetext{
${ }^{1}$ Senior Vice-President, Investment Strategy \& Research, Hancock Natural Resource Group, Boston, MA

${ }^{2}$ Assistant Dean, External Relations, Faculty of Forestry, University of
} British Columbia, Vancouver, B.C.
Au cours de la décennie allant de 1988 à 1998, les dépenses en recherche du secteur forestier en Colombie-Britannique ont augmenté substantiellement en termes absolus mais ont diminué par rapport à l'envergure des entreprises forestières de la province. Ces tendances globales masquent d'importantes modifications au niveau des sources de financement et dans les domaines spécifiques de recherche qui ont été financés. La corporation publique Forest Renewa BC est devenue la source principale de financement de la recherche forestière, déplaçant avec évidence les fonds appropriés en provenance du Ministère des Forêts de la Colombie-Britannique. Suite à la réduction des droits de coupe et suite aux changements survenus dans la politique forestière, cette source de financement est actuellement en déclin et la sécurité à long terme du programme de recherche du Forest Renewal BC est remise en question. En ce moment, les dépenses en recherche forestière sont plus ou moins équivalentes aux dépenses en recherche forestière effectuées dans d'autres juridictions où la foresterie est prédominante, mais le déclin anticipé du financement du programme de recherche du Forest Renewal BC modifie négativement cette situation autrement favorable. Les dépenses pour la recherche sur les produits forestiers dans la province ne sont pas équivalentes à leurs contreparties ailleurs dans le monde, et ont récemment diminué de façon précipitée. La foresterie - conservation de la forêt, aménagement, produits et processus de production - est de plus en plus en complexe. Les activités de recherche dans la province ne semblent pas être adéquates pour maintenir le flux de richesses économiques et écologiques en provenance des forêts dont les habitants de la Colombie-Britannique ont toujours joui et qu'ils s'attendent maintenant à recevoir.

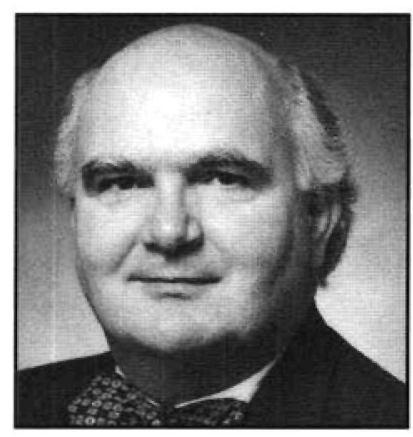

C.S. Binkley

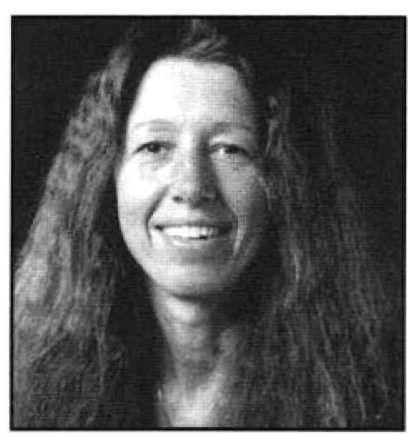

S.B. Watts

\section{The Survey}

We collected the data in two stages. The first was by using a two-page questionnaire mailed out in July 1998, and a telephone follow-up. The questionnaire was designed in cooperation with Dr. Robert Kozak, an expert in survey design. We identified the survey population through our respondents from the 1991/92 survey and through advice from members of BCFRAC, the Science Council of British Columbia and Forest Renewal BC. A total of 33 organizations received the questionnaire:

\section{Federal Government}

- Canadian Forest Service, Natural Resources Canada (CFS) 
- Natural Sciences and Engineering Research Council (NSERC)

- Canadian Wildlife Service, Environment Canada (CWS)

- Department of Fisheries and Oceans (DFO)

- National Research Council (NRC)

Provincial Government

- Science Council of B.C. (SCBC) / FRBC

- FRBC other (e.g., BC Advanced Systems Institute)

- B.C. Ministry of Forests (BCMoF)

- Ministry of Lands, Parks and Housing (MoELP)

Industry

- Western Forest Products Limited (WFP)

- MacMillan Bloedel (MB)

- Canadian Forest Products (CANFOR)

- TimberWest

- Weldwood

- Council of Forest Industries

- Coast Forest and Lumber Association

- Cariboo Lumber Manufacturers' Association

- Canadian Plywood Association

- Interior Lumber Manufacturers' Association (ILMA)

- Northern Forest Products Association (NFPA)

Research Organizations

- BC Research Inc. (BCRI)

- Forest Engineering Research Institute of Canada (FERIC)

- Forintek Canada Corp.

- Pulp and Paper Research Institute of Canada (PAPRICAN)

Universities and Colleges [recipient units in brackets]

- Okanagan University College [Science]

- College of New Caledonia [Forest Resource Technology]

- University College of the Cariboo [Science]

- Malaspina University College [Forest Resources Technology]

- British Columbia Institute of Technology [Renewable Resources and Biosciences]

- Simon Fraser University (SFU) [Science]

- University of Victoria (UVic) [Biology]

- University of British Columbia (UBC) [Forestry, Agriculture, Geography, Botany, Applied Science, Forest Economics \& Policy Analysis Research Unit, and Zoology]

- University of Northern British Columbia (UNBC) [Science]

Respondents were asked to report only that funding provided in the year 1997/98 from their own organization, or from a source agency not included in the survey. To this end, a covering letter accompanying each questionnaire provided a complete list of organizations being contacted for the project. In this way we hoped to be able to minimize the problem of double counting.

The questionnaire asked respondents to allocate their applicable 1997/98 forestry-related research expenditures (including operating expenses and salaries) among the ten research topics listed below:

1. Forest biology and ecosystem studies

2. Forest renewal

3. Growth and yield

4. Forest management planning and inventory

5. Non-timber resource management
6. Forest protection

7. Environmental impacts of forestry practices

8. Harvesting methods and technology

9. Forest products and processes

10. Economics, policy and social matters

The above categories match those of our first survey in 1991/92. Once again, our counting techniques require a warning to readers. While our procedures correctly identify the distribution of research expenditures among topics (1-10 above), they do not necessarily reflect the distribution of research effort among the actual research performers. For example, expenditures reported for universities reflect only (i) the contribution of provincially budgeted positions to research activities, and (ii) funds for research that have been obtained from sources other than those listed above. In the case of UBC, the research expenditures reported on our survey were $\$ 1.5$ million, although the actual research activity in 1997/98 totalled more than $\$ 9$ million (Faculty of Forestry 1998) with the difference coming from funding parties identified elsewhere in the survey. The data for other research organizations - e.g., FERIC, Forintek and PAPRICAN - are similarly affected. To avoid misinterpreting the results, the reader should understand the implications of counting expenditures in this way. The total expenditure for any one category fairly reflects the activity for that category. The total expenditure for any organization simply reflects the amount that that organization adds, on its own accord, or from "other sources," to the overall research enterprise.

Our updated survey included information-gathering on sub-categories within each of the ten main research categories. Questionnaire respondents were asked to identify their involvement in sub-category research topics by ticking the appropriate boxes. We did not ask for financial information at the sub-category level, but hoped to be able to count check marks as an indication of the intensity of research activity in specific areas.

The second stage of our data collection was conducted in November, 1998. An additional questionnaire was distributed to those organizations that had indicated research expenditures for 1997/98. In this survey, respondents were asked to estimate their research expenditures for the year 1998/99, using the same ten categories and the same method of counting described earlier.

\section{Results}

Our results are divided into three sections. We first discuss the status of forestry research in 1997/98 based on the survey described above. We then compare the current situation with the findings of earlier surveys, both ours and others. Because of the enormous flux in forestry R\&D at the moment, our third section provides a glimpse at the more recent trends.

\section{Status of Forest Sector Research in 1997/98}

Twenty-six organizations responded to our questionnaire and reported research expenditures in 1997/98. Four organizations (College of New Caledonia, University College of the Cariboo, Department of Botany at UBC, Coast Forest and Lumber Association, and the Council of Forest Industries) responded with "zero dollars to report." No response was received from another five organizations (Malaspina University College, Faculty of Agriculture at UBC, Forest Economics and Policy Analysis 


\begin{tabular}{|c|c|c|c|c|c|c|c|c|c|c|c|}
\hline & \multicolumn{11}{|c|}{ Topic } \\
\hline & 1 & 2 & 3 & 4 & 5 & 6 & 7 & 8 & 9 & 10 & Totals \\
\hline \multicolumn{12}{|l|}{ Industry } \\
\hline WFP & 8 & 21 & 122 & 70 & 95 & 3 & 0 & 0 & 0 & 0 & 319 \\
\hline MB & 28 & 64 & 251 & 137 & 0 & 0 & 0 & 0 & 12000 & 0 & 12480 \\
\hline CANFOR & 0 & 0 & 0 & 0 & 0 & 0 & 0 & 0 & 3655 & 0 & 3655 \\
\hline TimberWest & 0 & 2 & 0 & 0 & 0 & 0 & 0 & 0 & 0 & 0 & 2 \\
\hline Weldwood & 0 & 16 & 0 & 0 & 0 & 0 & 0 & 0 & 0 & 0 & 16 \\
\hline Cdn. Plywood Assn. & 0 & 0 & 0 & 0 & 0 & 0 & 0 & 0 & 1369 & 1290 & 2659 \\
\hline ILMA & 0 & 40 & 0 & 0 & 0 & 0 & 0 & 0 & 0 & 0 & 40 \\
\hline NFPA & 0 & 0 & 0 & 0 & 0 & 0 & 0 & 0 & 15 & 856 & 871 \\
\hline Total & 36 & 143 & 373 & 207 & 95 & 3 & 0 & 0 & 17039 & 2146 & 20041 \\
\hline \multicolumn{12}{|c|}{ Research Organizations } \\
\hline BCRI & 0 & 1150 & 0 & 0 & 0 & 50 & 0 & 0 & 0 & 0 & 1200 \\
\hline FERIC & 0 & 54 & 0 & 0 & 0 & 0 & 128 & 756 & 0 & 0 & 938 \\
\hline Forintek & 0 & 0 & 452 & 0 & 0 & 0 & 0 & 0 & 4615 & 0 & 5068 \\
\hline PAPRICAN & 0 & 0 & 0 & 0 & 0 & 0 & 0 & 0 & 5530 & 0 & 5530 \\
\hline Total & 0 & 1204 & 452 & 0 & 0 & 50 & 128 & 756 & 10145 & 0 & 12736 \\
\hline \multicolumn{12}{|c|}{ Universities And Colleges } \\
\hline Okanagan U Coll & 6 & 0 & 0 & 0 & 24 & 0 & 0 & 0 & 0 & 0 & 30 \\
\hline SFU & 458 & 21 & 8 & 0 & 19 & 21 & 19 & 0 & 0 & 0 & 546 \\
\hline UVic & 1035 & 261 & 0 & 0 & 0 & 0 & 0 & 0 & 0 & 0 & 1296 \\
\hline UBC & 374 & 74 & 57 & 96 & 122 & 85 & 17 & 77 & 414 & 225 & 1539 \\
\hline UNBC & 195 & 39 & 39 & 189 & 293 & 39 & 190 & 15 & 52 & 160 & 1210 \\
\hline Total & 2068 & 394 & 103 & 284 & 458 & 144 & 226 & 93 & 466 & 385 & 4621 \\
\hline \multicolumn{12}{|l|}{ Provincial } \\
\hline SCBC/FRBC & 3674 & 8809 & 4178 & 2612 & 845 & 1834 & 8488 & 604 & 2347 & 2144 & 35535 \\
\hline FRBC other & 0 & 0 & 0 & 0 & 0 & 0 & 0 & 399 & 572 & 0 & 971 \\
\hline $\mathrm{BCMoF}$ & 1811 & 7636 & 2571 & 838 & 2773 & 768 & 287 & 180 & 32 & 434 & 17330 \\
\hline MoELP & 0 & 0 & 0 & 0 & 315 & 0 & 0 & 0 & 0 & 0 & 315 \\
\hline Total & 5485 & 16446 & 6749 & 3449 & 3932 & 2603 & 8775 & 1183 & 2951 & 2578 & 54151 \\
\hline \multicolumn{12}{|l|}{ Federal } \\
\hline NSERC & 693 & 77 & 66 & 166 & 154 & 513 & 52 & 0 & 777 & 0 & 2499 \\
\hline CFS & 3394 & 1254 & 0 & 3702 & 0 & 2929 & 3242 & 300 & 1300 & 1000 & 17121 \\
\hline CWS & 100 & 0 & 0 & 0 & 0 & 0 & 0 & 0 & 0 & 0 & 100 \\
\hline DFO & 40 & 0 & 0 & 0 & 90 & 0 & 205 & 0 & 0 & 0 & 335 \\
\hline NRC & 0 & 0 & 0 & 0 & 0 & 0 & 0 & 0 & 2 & 0 & 2 \\
\hline Total & 4227 & 1331 & 66 & 3868 & 244 & 3443 & 3499 & 300 & 2079 & 1000 & 20057 \\
\hline Research Totals & 11816 & 19518 & 7744 & 7809 & 4729 & 6242 & 12628 & 2331 & 32680 & 6110 & 111606 \\
\hline
\end{tabular}

Key to topics:

1. Forest biology and ecosystem studies.

2. Forest renewal.

3. Growth and yield.

4. Forest management planning and inventory.

5. Non-timber resource management.

6. Forest protection.

7. Environmental impacts of forestry practices.

8. Harvesting methods and technology.

9. Forest products and processes.

10. Economics, policy and social matters

Research Unit at UBC, British Columbia Institute of Technology and the Cariboo Lumber Manufacturers Association).

Table 1 presents the results of this survey. Remember that the entries for any one organization do not necessarily reflect the levels of research activity for that particular organization but rather funding arising from that source.

In 1997/98, a total of $\$ 111.6$ million was spent on forestry and forest products research. By far the highest level of forestry-related research funding was recorded in topic \#9, forest products and processes, which represented $\$ 32.68$ million of the total (note, however, that this category is extremely broad and covers a wide range of areas). The lowest level of funding was recorded in topic \#8, harvesting methods and technology, at $\$ 2.33$ million, or $2.1 \%$ of the total. Given both the high logging costs in B.C. (at least on the Coast) and the environmental concern about harvest practices, this low level of expenditure on harvesting research is surprising.

Fig. 1 shows the relative amounts of forest sector research funding for each of the ten topics in our current, 1997/98 survey and a comparison with our earlier 1991/92 survey of the same topics. In the current survey, forest products and processes account for $29.3 \%$ of the total (down from $41.3 \%$ in 1991/92). Research on forest renewal is the next largest category equalling about $17.5 \%$ of the total and about $24.7 \%$ of the total research devoted to forestry. This large share is not surprising given Forest Renewal BC's substantial commitment to forest renewal and research.

Fig. 2 depicts the relative levels of funding by funding source. Provincial sources - the provincial government and Forest Renewal $\mathrm{BC}$ - provide almost $50 \%$ of the funding for forest sector 


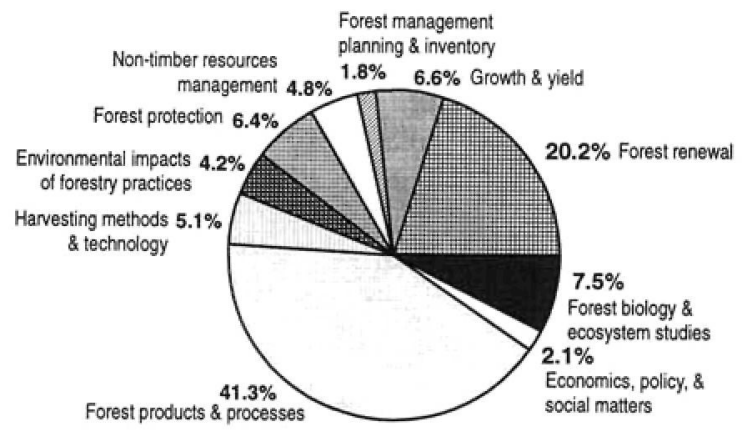

1991/92

Total expenditures $=\$ 71.1$ million

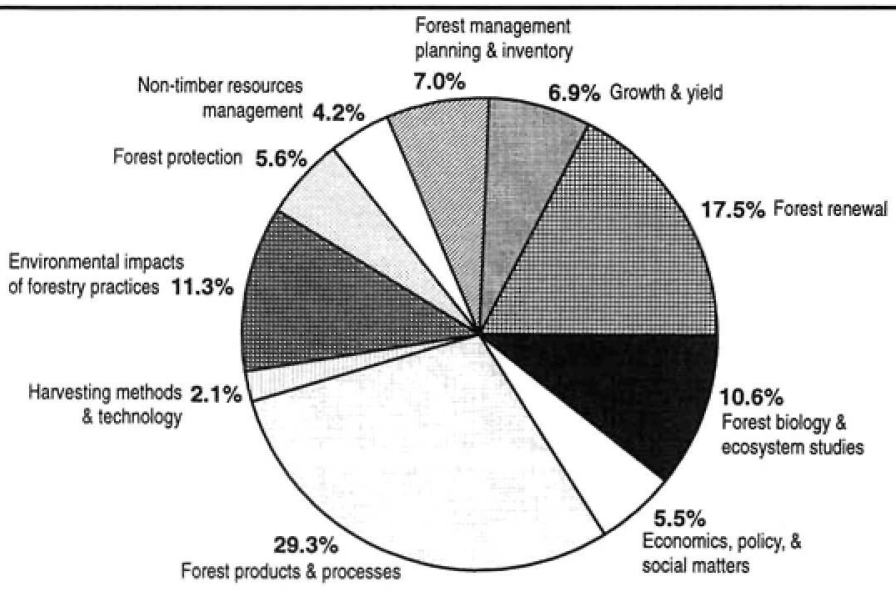

$1997 / 98$

Total expenditures $=\$ 111.6$ million

Fig. 1. Forest sector research funding by topic, 1991/92 \& 1997/98.

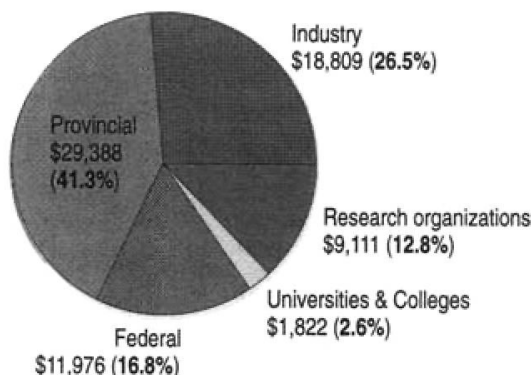

$1991 / 92$

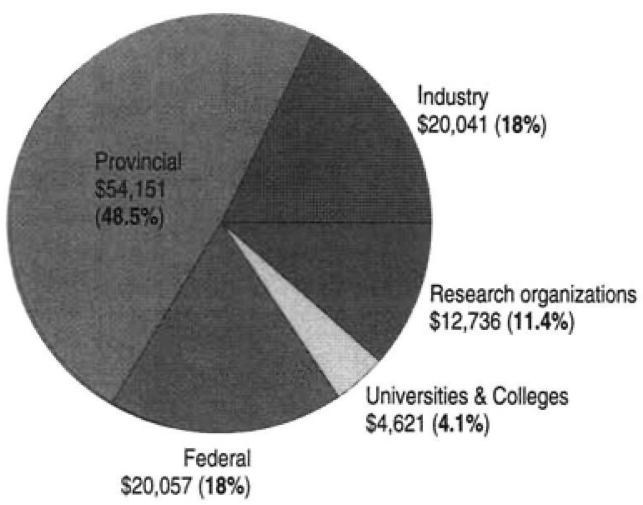

$1997 / 98$

Fig. 2. Forest sector research funding by source (\$000), 1991/92 \& 1997/98.

research in B.C. The federal government and the forest industry each provide $18 \%$ of forest sector research funding. Eighty-five percent of the forest industry's research funding is applied to forest products research. B.C.'s forest tenure arrangements readily explain the lack of forest industry focus on forestry research, although it is not at all clear that this result best serves the people of British Columbia.

Fig. 3 and Fig. 4 present the total funding by source for, respectively, forestry and forest products research. Provincial funding for forestry research is divided among forest renewal $(30.4 \%)$, environmental impacts $(16.2 \%)$, growth and yield $(12.5 \%)$ and forest biology (10.1\%). Federal support centres largely on forest biology (22.9\%) and forest management $(20.9 \%)$, with both environmental impacts and forest protection close runners up at $18.6 \%$.

Forest products research is funded primarily by industry $(52.1 \%)$ and research organizations $(31.0 \%)$. Federal and provincial sources provide, respectively, $9.0 \%$ and $6.4 \%$ of the total support for forest products research.

\section{Decadal Trends in Forest Sector Research}

During the past decade, science and technology have become central to the prosperity of many industries, and the forest sector is no exception. Have trends in R\&D expenditures matched the need? Table 2 shows the trends in forest sector research funding between the two survey periods.

In total, research expenditures have increased by about $\$ 40.5$ million, or about $57 \%$. Nearly two thirds $(61.1 \%)$ of the increase has come from provincial sources. Forest Renewal $\mathrm{BC}$ has emerged as by far the dominant source of research support in the Province. The increases in Forest Renewal BC R\&D expenditures have offset a dramatic $\$ 8.5$ million decline in research activity in the B.C. Ministry of Forests. Increased funding by the federal government was the second largest source of additional funding, with CFS making up the vast majority of the increase. The modest increase in NSERC expenditures is most likely related to (i) the Sustainable Forest Management NCE project which, while centred in Alberta, has supported research in B.C., and (ii) increased matching funds in the various research partnership programs made possible 


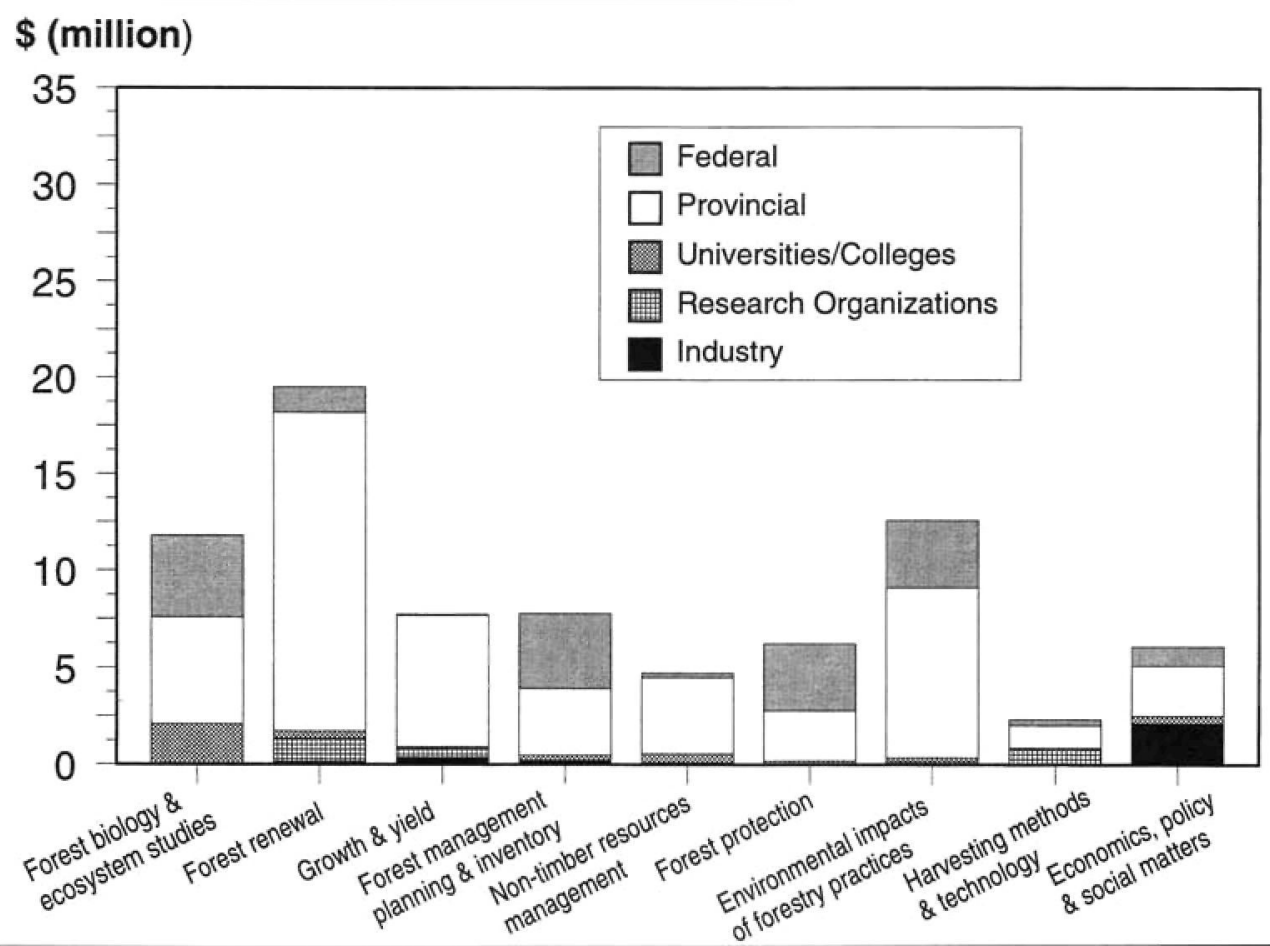

Fig. 3. Funding for forestry research (excluding forest products) by source, 1997/98.

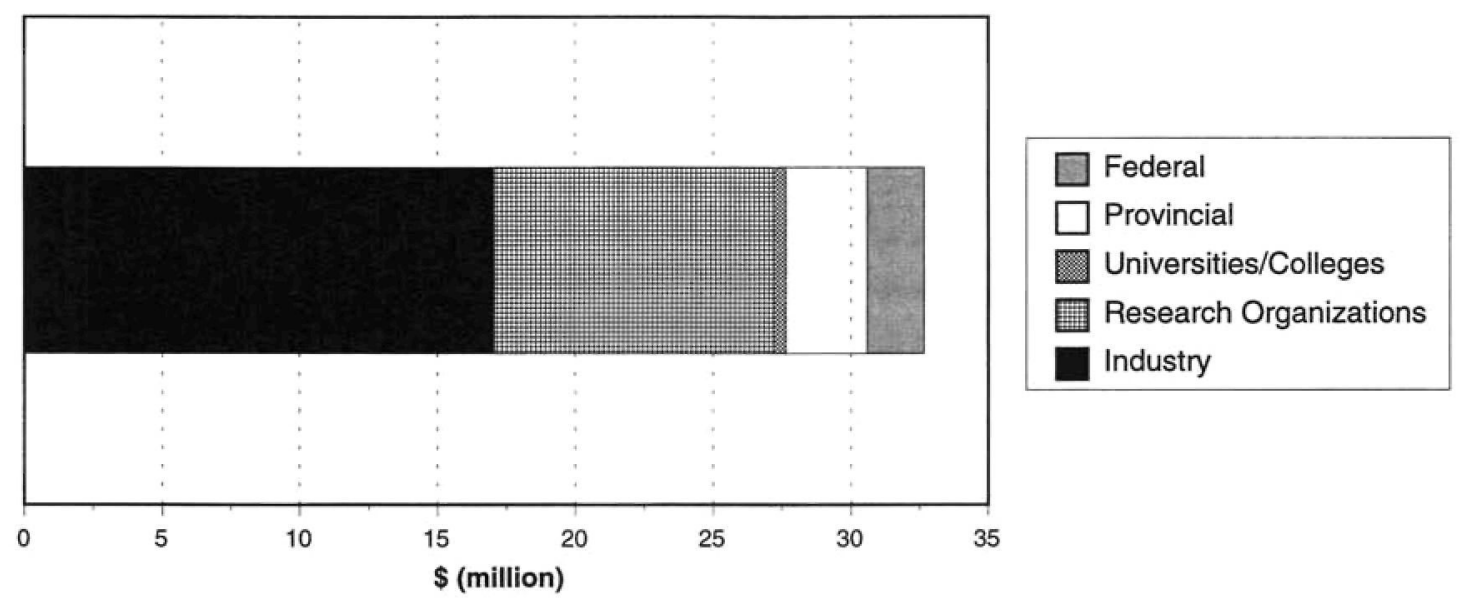

Fig. 4. Funding for forest products research by source, 1997/98.

through increased research support from other providers. Most of the increase in University/College expenditures arises from the incremental income afforded by endowments provided by Forest Renewal BC, the industry and the federal government.

It is useful to examine the separate trends for the various categories of research. Expenditures on forestry research have increased $89.2 \%$, from $\$ 41.7$ million in 19991/92 to $\$ 78.9$ million in the most recent survey. In contrast, expenditures on forest products research have risen only $11.3 \%$, from $\$ 29.4$ million in 1991/92 to $\$ 32.7$ million in $1997 / 98$.

More detailed trends in the sources of forestry research support are shown in Fig. 5 for the full decade between 1988/89

\begin{tabular}{lrrrr}
\hline \multicolumn{5}{l}{ Table 2. Trends in forest sector research funding (\$ million), 1991/92-1997/98. } \\
\hline & $\mathbf{1 9 9 1 / 9 2}$ & $\mathbf{1 9 9 7 / 9 8}$ & Change & $\begin{array}{r}\text { \% of Total } \\
\text { Difference }\end{array}$ \\
\hline Provincial government & 29.388 & 54.151 & 24.763 & $61.1 \%$ \\
Federal government & 11.976 & 20.057 & 8.081 & $20.0 \%$ \\
Industry & 18.809 & 20.041 & 1.232 & $3.0 \%$ \\
Research organizations & 9.111 & 12.736 & 3.625 & $9.0 \%$ \\
Universities \& colleges & 1.822 & 4.621 & 2.799 & $6.9 \%$ \\
Total & $\mathbf{7 1 . 1 0 6}$ & $\mathbf{1 1 1 . 6 0 6}$ & $\mathbf{4 0 . 5 0 0}$ & $\mathbf{1 0 0 . 0 \%}$ \\
\hline
\end{tabular}

and present. The obvious, significant change is the emergence of Forest Renewal BC as the leading supporter of forestry research in the province ( $\$ 36.6$ million in 1997/98). After a surge in 


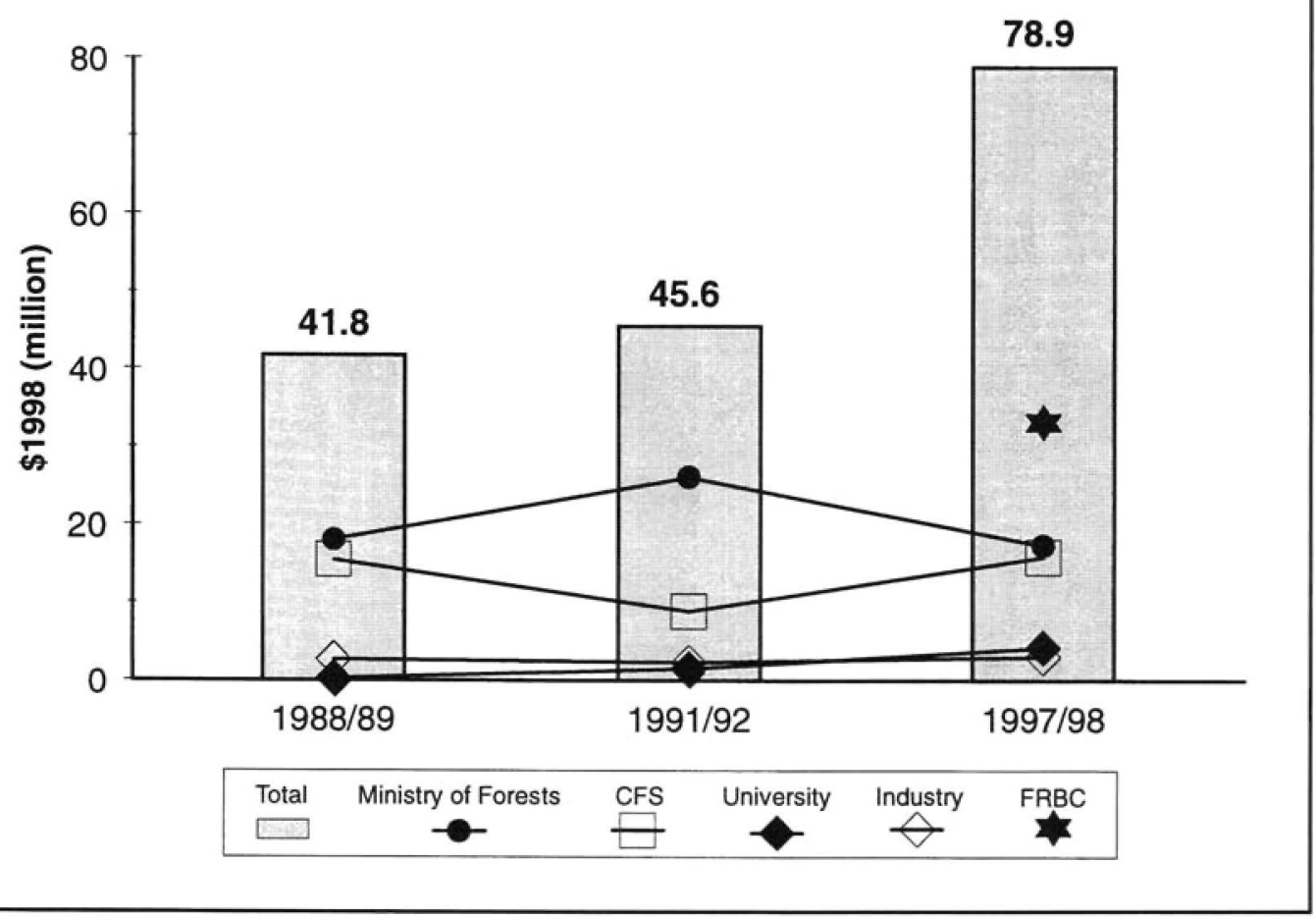

Fig. 5. Trends in forestry research support by source, in real terms $(\$ 1998)$, $1988 / 89-1997 / 98$. research funding in the early 1990s (possibly associated with the Federal/ Provincial FRDA program), the research budget of the B.C. Ministry of Forests has remained virtually unchanged over the decade. Research funding at CFS dipped in the early 1990s but recovered to about the same level it was 10 years ago. University funding for forestry and forest products research has grown dramatically in percentage terms, albeit from a tiny base. With the important exception of the emergence of Forest Renewal BC's research program - a program that is in jeopardy - stasis has characterized forestry research in B.C. over the past decade.

In the past ten years much has changed in forestry and in the forest sector. As a consequence, it is difficult to judge the adequacy of these expenditures. One imperfect but commonly accepted means of doing so denominates R\&D expenditures as a fraction of industry sales. To be most useful, the calculation requires a careful definition of the specific industry. The B.C. forest sector comprises two related but separate industries. The first is forestry - the management of forests and the production of commercially valuable timber. The second is forest products manufacturing including the pulp, paper and solid wood products industries. This distinction is particularly relevant in B.C. because there is very little private sector forestry business per se since provincial policy reserves virtually all profitable aspects of tree growing and forest management for the provincial government. We have used data on the value of industry shipments from COFI and estimates from PricewaterhouseCoopers on the value of logs and chips to separate B.C.'s "forestry" revenues from those arising from the forest products manufacturing industry. Using these data and our estimate of forestry and forest products $R \& D$ expenditures produces the results in Table 3 .

Overall, when expressed as a fraction of total sales, forestryrelated R\&D has weakened modestly over the past six years,
Table 3. Comparisons of forestry and forest industry GERD.

\begin{tabular}{lccr}
\hline & $1991 / 92$ & $1997 / 98$ & \% Change \\
\hline TOTAL $(\$ 111.6 / \$ 16834)^{\mathrm{a}}$ & 0.69 & 0.66 & $-4.3 \%$ \\
Forestry $(\$ 78.9 / \$ 5973)^{\mathrm{b}}$ & 1.22 & 1.32 & $8.2 \%$ \\
Forest products $(\$ 32.7 / \$ 10861)^{\mathrm{c}}$ & 0.43 & 0.30 & $-30.2 \%$ \\
\hline
\end{tabular}

${ }^{a}$ B.C. forest industry shipments ( $\$ 16834$ million) is the COFI figure for 1997 forest industry value of shipments.

${ }^{b}$ Forestry enterprise ( $\$ 5973$ million) is the PricewaterhouseCoopers figure for the value of logs and chips delivered to manufacturing plants in 1997.

${ }^{c}$ Forest products enterprise ( $\$ 10861$ million) is the value of shipments less the forestry enterprise figure.

with contrary trends for forestry and the forest products sectors. Forestry R\&D has strengthened and is now approaching the levels found in other advanced forested jurisdictions. In contrast, R\&D on forest products has fallen dramatically from levels that were already quite low by international standards. With this low and declining focus on R\&D, it is unlikely that the B.C. forest industry will be able to adapt to the turmoil of contemporary forest products markets.

\section{More-recent Trends in Forest Sector R\&D}

The past few years have been ones of great change in B.C.'s forest sector. The collapse of markets in Asia, the imposition of the Softwood Lumber Agreement with the U.S., and the full enforcement of the Forest Practices Code have placed great financial stress not only on the industry but also on the provincial government. Companies are cutting expenses and R\&D has been vulnerable when the very existence of a company is at stake. The "super stumpage" supporting Forest Renewal $\mathrm{BC}$ has declined with lower lumber prices, and industry participants - labour, companies and communities are clamouring for a larger share of Forest Renewal BC's shrinking revenues. Given these significant changes in the forest sec- 
Table 4. Forest sector research support (\$ million), $1997 / 98$ and estimates for 1998/99.

\begin{tabular}{lcrc}
\hline Source & $\begin{array}{c}\mathbf{1 9 9 8 / 9 9} \\
\text { estimates }\end{array}$ & $\mathbf{1 9 9 7 / 9 8}$ & \% change \\
\hline Federal government & 21.186 & 20.057 & 5.6 \\
Provincial government & 43.252 & 54.151 & -20.1 \\
Industry & 6.681 & 20.041 & -66.7 \\
Research organizations & 11.774 & 12.736 & -7.5 \\
Universities \& colleges & 4.355 & 4.621 & -5.8 \\
Total & $\mathbf{8 7 . 2 4 8}$ & $\mathbf{1 1 1 . 6 0 6}$ & $\mathbf{- 2 1 . 8}$ \\
\hline
\end{tabular}

tor, we asked the same sample of respondents to estimate their 1998/99 research expenditures.

Table 4 shows estimated expenditures by source for $1998 / 99$. On the positive side, federal support for forest sector R\&D is increasing modestly, up \$1.1 million in CFS and about $\$ 0.25$ million in NSERC. Unfortunately, the reductions are more substantial than the increases. The most notable is the enormous reduction $-\$ 13.3$ million, or $66.7 \%$ - in industry-sponsored R\&D. This reflects the closure of MacMillan Bloedel's research centre and a major reduction in CANFOR's research activities. The already low level of forest products R\&D in the province has shrunk to levels unimaginable in other developed jurisdictions where the forest industry is important - Sweden, Finland or the United States. Second, the downward pressure on the B.C. Ministry of Forests research program continues, falling from $\$ 17.3$ million in 1997/98 to an estimated $\$ 13.9$ million in 1998/99. Third, Forest Renewal BC's R\&D program is declining by $\$ 7.5$ million. This reduction in support is particularly worrisome since Forest Renewal BC support displaced direct provincial support for R\&D in the B.C. Ministry of Forests. The factors behind lower Forest Renewal BC research support - declining lumber prices and increased E. demands from other elements of the forest sector - are unlike2.ly to soon abate. Hence, one can anticipate further erosion of Dot this source of research support.

\section{Conclusions}

Forest sector R\&D in British Columbia remains low by international standards, and the aggregate trends suggest further declines in the near future. With the advent of the Forest Renew- al BC Research Program, the situation had become relatively positive for forestry R\&D, but this generally favourable circumstance is clouded by the very recent decline of $R \& D$ support from Forest Renewal BC. This decline is likely to continue, and is exacerbated by the concomitant decline in the B.C. Ministry of Forest's research program. Indeed, one negative effect of Forest Renewal BC's progressive support of forestry $R \& D$ was to permit the provincial government to reduce its own commitment to the sector.

The situation with forest products R\&D has become dire. MB's world-class research facility no longer exists, and much of the talent has left the province. The only other B.C. company with a material commitment to forest products $R \& D$ - CANFOR - is reducing its expenditures by one third. Forintek's budget is not keeping pace with general inflation. It is difficult to see how B.C.'s forest products companies can meet the challenges of the future with so little attention to $R \& D$.

In the present context, $R \& D$ is best seen as an element of industrial strategy. Viewed in this light, companies will perform $R \& D$ only to the extent that it generates positive returns on the funds invested. Governments will perform $R \& D$ only to the extent that either they, too, receive some return on the capital invested or that they need the results for regulatory decisions. As seen from this vantage point, the low and declining level of forest sector R\&D in B.C. is deeply troubling. Evidently, innovation derived from $R \& D$ is no longer an effective business strategy in B.C. We urge the provincial government to renew its commitment to the importance of a knowledgebased forest sector to the prosperity of British Columbians.

\section{Acknowledgements}

This project was commissioned by the Council of Forest Research Agencies. Funding was provided by Forest Renewal BC - a partnership of forest companies, workers, environmental groups, First Nations, communities and government.

\section{References}

Binkley, C.S. and S.B. Watts. 1992. The Status of Forestry Research in British Columbia. For. Chron. 68(6): 730-735.

Faculty of Forestry. 1998. 1997 Annual Report, Faculty of Forestry, University of British Columbia, Vancouver, B.C. ISSN 1188-9837. $55 \mathrm{p}$. 